\title{
Accidental self-administration of an epinephrine autoinjector by a toddler
}

\author{
Sarah Edgerley MD, Rongbo Zhu MD, Samira Jeimy MD PhD
}

Cite as: CMAJ 2021 April 26;193:E616. doi: 10.1503/cmaj.201798

A 3-year-old boy presented to the emergency department with acute left knee pain and inability to bear weight with his left leg. He had a peanut allergy, for which he had been prescribed an epinephrine autoinjector. Five days before presentation, he had taken his autoinjector from his mother's purse and had accidentally selfadministered it into his left knee before his mother could stop him.

Examination showed a warm, swollen, erythematous joint with limited active and passive range of motion. A small puncture wound was visible on the lateral aspect of the knee at the site of epinephrine administration (Figure 1). A radiograph showed a large effusion in the suprapatellar recess. Laboratory analysis showed a normal white blood cell count of 9.5 (normal range $5.0-12.0) \times 10^{9} / \mathrm{L}$, an elevated C-reactive protein level of 81.6 (normal range $0-5.0) \mathrm{mg} / \mathrm{L}$ and an elevated erythrocyte sedimentation rate of 97 (normal range $0-10$ ) $\mathrm{mm} / \mathrm{h}$. We diagnosed septic arthritis. The patient underwent urgent joint irrigation and débridement under general anesthesia, which yielded approximately $50 \mathrm{~mL}$ of purulent material. Specimen cultures tested positive for Staphylococcus aureus. We prescribed cefazolin in hospital, followed by 6 weeks of cephalexin. After discharge from hospital, the patient continued to carry his epinephrine autoinjector.

Intramuscular epinephrine autoinjectors are the first-line therapy for anaphylaxis. ${ }^{1}$ With increasing rates of food allergies, rates of prescriptions for epinephrine autoinjectors have also risen. ${ }^{1}$ Accidental epinephrine administration is an infrequent complication, occurring once per 50000 autoinjectors prescribed. ${ }^{2}$ About $45 \%$ of patients injured are children younger than 11 years. ${ }^{1}$ Fingers are the most common sites of accidental injections, with temporary and mild consequences. ${ }^{1,2}$ Treatment is supportive, although phentolamine, terbutaline and nitroglycerin may be used for digital ischemia. ${ }^{2}$

Current guidelines do not specify a minimum age at which children can self-administer epinephrine; this decision is based on patient maturity and demonstration of adequate technique. As the benefits of carrying epinephrine autoinjectors far outweigh the risks, patients should be referred to instructional materials available on manufacturer websites, and should be equipped with training kits and an anaphylaxis action plan. ${ }^{3}$

\section{References}

1. Simons FER, Edwards ES, Read EJ, et al. Voluntarily reported unintentional injections from epinephrine auto injectors. J Allergy Clin Immunol 2010;125:419-23.e4.

2. Mathez C, Favrat B, Staeger P. Management options for accidental injection of epinephrine from an autoinjector: a case report. J Med Case Rep 2009;3:7268.

3. Anaphylaxis emergency plan. Toronto: Food Allergy Canada. Available: https:// foodallergycanada.ca/tools-and-downloads/downloads/emergency-plan-forms/ (accessed 2020 Oct. 12).

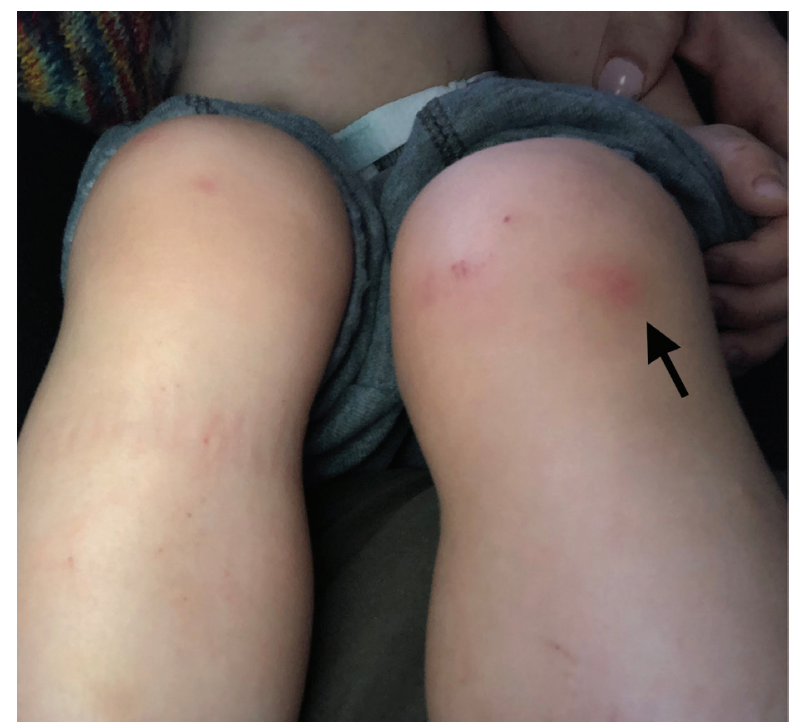

Figure 1: Septic arthritis in a 3-year old boy. Photograph of the patient's swollen left knee. A small area of erythema is noted on the lateral aspect of the left knee at the site of accidental epinephrine autoinjector administration.

Competing interests: Samira Jeimy reports having been on speaker's bureaus for Aralez, AstraZeneca, Sanofi, Medexus, Stallergenes Grier and Novartis, and on the advisory board for Sanofi. No other competing interests were declared.

This article has been peer reviewed.

The authors have obtained parental consent.

Affiliations: Schulich School of Medicine \& Dentistry (Edgerley, Zhu, Jeimy), and Division of Clinical Immunology and Allergy (Zhu, Jeimy), Department of Medicine, Western University, London, Ont.

Content licence: This is an Open Access article distributed in accordance with the terms of the Creative Commons Attribution (CC BY-NC-ND 4.0) licence, which permits use, distribution and reproduction in any medium, provided that the original publication is properly cited, the use is noncommercial (i.e., research or educational use), and no modifications or adaptations are made. See: https://creativecommons.org/licenses/by-nc-nd/4.0/

Correspondence to: Samira Jeimy, samira.jeimy@lhsc.on.ca 